\title{
Fuel-Mining Exports and Economic Growth: Evidence from the UAE
}

\author{
Trevor W. Chamberlain ${ }^{1}$ Athanasia S. Kalaitzi ${ }^{2}$
}

A number of studies have described the positive impact of export expansion on economic growth, through enhanced economies of scale, adoption of advanced technologies and greater capacity utilization (Feder, Journal of Development Economics, 1982; Lucas, Journal of Monetary Economics, 1988; Al-Yousif, Applied Economics, 1997; Vohra, International Advances in Economic Research, 2001; Abou-Stait, Economic Research Working Paper Series, 2005). However, other studies have found that exports have a negative effect on economic growth (Myrdal, Economic Theory and Under-developed Regions, 1957; Meier, Leading Issues in Economic Development, 1970; Lee and Huang, Journal of Economic Development, 2002; Kim and Lin, Journal of Development Studies, 2009). This may be because primary exports in some countries constitute a large share of total exports. Primary exports are often subject to large price fluctuations and seldom offer the knowledge spillovers and other externalities of manufactured good exports (Herzer et al., Developing Economies, 2006; Kalaitzi and Cleeve, Eurasian Business Review, 2018).

These contradictory findings have encouraged investigation of the impact of export categories on economic growth, as aggregate measures may mask differences in the causal effects of export subcategories. The United Arab Emirates (UAE) is one country that relies heavily on primary (fuel-mining) exports and, yet, has grown quickly. However, there is no published evidence on the causal relationship, if any, between fuel-mining exports and economic growth.

The present study examines the causal effect of fuel-mining exports on economic growth over the period 1981-2012, using a model in which aggregate production is expressed as a function of physical capital, human capital, fuel-mining exports and imports of goods and services. The data sources are the World Bank, World Trade Organization, International Monetary Fund and UAE Bureau of Statistics.

The time series properties of the variables are examined using the augmented Dickey-Fuller and Phillips-Perron unit root tests, and a unit root test with a structural break (Saikkonen and Lutkepohl, Econometric Theory, 2002). To investigate the existence of a long-run relationship between fuel-mining exports and economic growth, the study applies the Johansen co-integration test. The direction of short-run causality is examined by applying the Granger test in a vector error- correction framework. A modified Wald test in an augmented auto-regressive model (Toda and Yamamoto, Econometrics, 1995), is used to investigate the presence of long-run causality.

\footnotetext{
${ }^{1}$ DeGroote School of Business, McMaster University, 1280 Main Street West, Hamilton, Ontario, Canada L8S 4M4, Tel: (905) 525-9140, x23980 E-mail: chambert@mcmaster.ca

${ }^{2}$ Middle East Centre, London School of Economics and Political Science, WC2A 2AZ, London, UK, Tel: +44 (0) 7547371547 Email: a.kalaitzi@1se.ac.uk
} 
After taking first differences for all variables examined, the null hypothesis of a unit root can be rejected $(p<0.05)$. As for Johansen's co-integration test, the null hypothesis of no co-integration is rejected $(p<0.05)$, indicating the presence of one co-integrating vector.

The Granger causality tests indicate that the hypothesis of no short-run causality from fuel-mining exports to economic growth cannot be rejected $(p=0.058)$. The null hypothesis of no causality from economic growth to fuel-mining exports also cannot be rejected $(\mathrm{p}=0.720)$.

As for the other relationships in the model, uni-directional short-run causality runs from physical capital to fuel-mining exports $(\mathrm{p}=0.025)$, while fuel-mining exports cause imports $(p=0.003)$. These results suggest that investment in physical capital increases fuel-mining exports, allowing imports of capital goods to expand, improving productivity and fostering economic growth. A chi- square test of the joint significance of the explanatory variables indicates that economic growth, changes in physical and human capital, and fuel-mining export growth jointly cause an increase in total imports $(\mathrm{p}=0.029)$.

The Toda-Yamamoto tests for long-run causality show that the null hypothesis that fuel-mining exports do not Granger-cause GDP cannot be rejected ( $p=0.306$ ). This is evidence of the productivity-limiting effects of fuel-mining exports. Likewise, there is no evidence of long-run causality from GDP to fuel-mining exports.

In contrast, a long-run bi-directional causality exists between total imports and economic growth. This suggests that economic growth can increase the capacity to import essential materials for domestic production, improving existing technology and leading to further economic growth. At the same time, long-run causality runs from both physical capital and imports to fuel-mining exports $(\mathrm{p}=0.006$ and $\mathrm{p}=$ 0.021 respectively), suggesting that investments in advanced technology and imports contribute to the expansion of fuel-mining exports. In addition, an indirect causal relationship exists through the impact of GDP on imports and imports on fuel-mining exports (with $p=0.002$ and $p=0.021$ respectively). Finally, in the long run, GDP, physical and human capital, and imports jointly cause fuel-mining exports, while GDP, physical and human capital, and fuel- mining exports jointly cause imports (both at $\mathrm{p}=0.008$ ).

Overall, the co-integration analysis confirms the existence of a relationship between GDP, physical and human capital, fuel-mining exports and total imports, while fuel-mining exports are found to have a negative impact on economic growth. At the same time, the study finds that fuel-mining exports do not cause economic growth in the short-run or the long-run. Fuel-mining exports as a proportion of total merchandise exports have been steadily decreasing since 1981. Further reductions in the relative importance of fuel-mining exports should enhance the rate of economic growth in the UAE, through greater imports and physical capital accumulation.

Finally, it should be noted that the UAE economy has structural characteristics that may differ from those of non-Gulf Cooperation Council; oil-producing countries and this may limit the generalizability of our findings. However, we believe that the results of this study do contribute, at a minimum, to the discourse on future policies for sustaining economic growth in the UAE and in other countries in the Gulf region. 